\title{
DETERMINATION OF THE SPREAD OF HEAVY METAL FROM ORI-ILE BATTERY WASTE DUMPSITE USING ELECTRICAL RESISTIVITY METHOD
}

\author{
Mutiu A. Fakunle ${ }^{1}$, James A. Adegoke ${ }^{2}$, Joseph O. Enemali ${ }^{2}$ \\ ${ }^{I}$ Department of Physics, Osun State University, Osogbo, Nigeria, P.M.B.4494, Osogbo, Nigeria \\ ${ }^{2}$ Department of Physics, University of Ibadan, Ibadan Nigeria
}

\begin{tabular}{|c|c|}
\hline Article Info & Abstract \\
\hline $\begin{array}{l}\text { Keywords: } \\
\text { Heavy metal. Battery } \\
\text { wastes, water analysis, } \\
\text { electrical resistivity, } \\
\text { apparent conductivity, } \\
\text { lead concentration }\end{array}$ & $\begin{array}{l}\text { Contaminants from waste dumpsites have become sources of concern. Disposed } \\
\text { wastes (Heavy metal) from battery industries could contaminate soil, agricultural } \\
\text { plants, and groundwater. Therefore, this study aimed at the determination of the } \\
\text { migration of heavy metal (Lead) from a Battery Waste Dumpsite using the } \\
\text { electrical resistivity method. Using Schlumberger array, fifteen (15) Vertical } \\
\text { Electrical Soundings (VES) were carried out around a Battery Waste Dumpsite in } \\
\text { Ori -Ile, Ikumapaiyi at Olodo community, Ibadan, Oyo State, Nigeria. Preliminary } \\
\text { analyses of VES data were performed and were fed into software (WINRESIST } \\
\text { 1.0) for qualitative interpretation to reveal apparent resistivity values, the number of } \\
\text { layers, and thickness. Three and four layers of topsoil, sandy-clayed, } \\
\text { weathered/fractured basement, and basement were obtained. Various values of } \\
\text { lowest apparent resistivity and depths of penetration of leached lead on the four } \\
\text { sides of the battery waste dumpsite were obtained. The lowest apparent resistivity } \\
\text { values obtained were converted to apparent conductivity and plotted against the } \\
\text { distance of each VES point. Five collected water samples from available hand-dug } \\
\text { wells around the dumpsite were analyzed for the presence of lead using an Atomic } \\
\text { Absorption Spectrometer. Graph of apparent conductivity against VES distance } \\
\text { indicated a decrease in conductivities with distance, an indication of reduction of } \\
\text { Concentration of lead with distance. The level of Lead ranged from } 0.081 \text { to } 0.770 \\
\text { mg/L which was above the tolerance level of } 0.01 \mathrm{mg} / \mathrm{L} \text { of WHO and SON, an } \\
\text { indication of heavy metal pollution in groundwater. This study has established that } \\
\text { lead ions were present in groundwater and had spread to a distance of } 80 \mathrm{~m} \text { from } \\
\text { the battery waste dumpsite and were more pronounced on the southern region of the } \\
\text { dumpsite. }\end{array}$ \\
\hline
\end{tabular}

\section{Introduction}

As the human population grows, the amount of waste produced multiplies as a result of human activities. Among the various wastes been generated include poultry wastes, industrial 
wastes, and household wastes obtained from activities like poultry farming, mining, manufacturing, smelting, anthropogenic activities, and household activities [1]. Industrial processes like manufacturing, smelting and mining could generate heavy metals. These heavy metals were described by [2]) as chemical elements with a specific gravity of at least five times that of water. Salem et al., (2000) [3] gave the specific gravity of some of these metals as 13.54 (Mercury), 11.34 (lead), 8.65 (Cadmium) and 7.9 (Iron). Some of these metals like lead (Pb) Cadmium $(\mathrm{Cd})$ and Mercury $(\mathrm{Hg})$ are found naturally in small quantities in foodstuffs, fruits, and vegetables and also in commercial products like multivitamins [4]. Naturally, these heavy metals are present in the soil and can be mined and become very useful components in automobile battery companies. So, during the manufacturing processes, the scrap of these heavy metals could be generated and the need to dispose of them arises. When these scraps are thrown into the soil, they add to the one already presents thereby increase the quantity then becomes a contaminant to soil and groundwater [5]. This increase caused by these heavy metals could result in plants, animals, and human health disorders [6]. The concentration of these toxic elements in soils could be increased by pollution from human activities, weathering of natural high background rocks, and metal deposits [7]. Chemical and metallurgical industries are the most important sources of heavy metals in the environment [8].

Poor management of these wastes could be hazardous to human life and the environment [4]. Thus, it becomes imperative to manage these wastes effectively. Methods such as landfills and open dumps have been fashioned out to manage these wastes [8] without minding what the effect would be on soil and groundwater. Disposal of waste of automobile batteries wastes on land and or open dumps is a major source of heavy metals contamination since these metals when rain and dew fall on them become corroded and penetrate the soil and groundwater [5] to contaminate them. The open dump is the mode of disposing wastes by automobile battery manufacturing companies in Nigeria and other developing countries [9]. Hand-dug wells and motorized boreholes which are now the major sources of water supply for domestic and industrial use in many parts of Nigeria [10] are now affected. Nwachukwu et al; (2010) [11] found out that these heavy metals are destructive, non - degradable and accumulate in the body once they enter the human body or plants. They could enter the human body through ingested food, water and air; they are absorbed and stay in human bodies rather than being excreted. This ability of bioaccumulation is one reason chronic exposure to heavy metal is hazardous [12]. 
Contamination of the groundwater by heavy metals is therefore a major threat to life and healthy living in Nigeria. Open land dumping has resulted in the degradation of valuable land resources and the creation of long-term environmental and human health problems [13]

The electrical conductivity of earth materials is influenced by the metal content in the rock, porosity, clay content, permeability, and degree of pore saturation [14]. The electrical conductivity is enhanced by the increase in the concentration of the ions of these heavy metals. In this study, the electrical resistivity method is used to measure the resistivity distribution of these ionic concentrations of these heavy metals as they migrate with groundwater since they have sufficiently high contrast in physical properties against the host media due to an increase in dissolved salts in the groundwater and a resulting decrease in pore water resistivity [15]

This method is based on the fact that when an electric current is driven into the earth through two metallic electrodes, any variation of the subsurface resistivity will alter the current flow, which will in turn affect the distribution of the electric potential. The measurement of the electrical potential and current on the earth's surface will make it possible to obtain information about the resistivity/conductivity variation of the subsurface in the survey area [16].

This research aimed to study the spread of some heavy metal contaminants in Ori-Ile battery dumpsite using the electrical resistivity method and the objectives are to ascertain the presence of heavy metals in the environment surrounding the dumpsite and to determine direction of spread of the heavy metals

\subsection{Description of the study site}

This study was carried out at Ori-ile (latitudes $7^{\circ} 24^{\prime} 28.1^{\prime \prime} \mathrm{N}$, longitudes $4^{\circ} 00^{\prime} 52.2^{\prime \prime} \mathrm{E}$ and elevation $(176.0 \mathrm{~m})$ in Omilende village in Ikumapaiyi Area of Olodo community, northwest of Egbeda Local Government Area, Ibadan, Oyo State. It is a semi-urban residential and agricultural area. It contained a waste dumpsite popularly referred to as Ori-Ile Waste Dumpsite or Ori-battery. The study site was used as an unapproved waste dumpsite for battery wastes from the inception to the closed down of the company. It was also used as an informal lead recovery site by lead-acid battery operators [17]. The climatic condition of the area is tropical with two major seasons: the rainy season from March to October and the dry season from November to February. The vegetation of the area is affected by the alternation of these two seasons. 


\subsection{Geology of the Study Site}

The study area is part of the basement complex of Southwestern Nigeria [13]. The dominant rock types in the region are quartzite, banded gneiss and granite gneiss of the Metasedimentary series, banded gneiss, augen gneiss and migmatite constituting the gneissmigmatite complex. Quartz schist outcrops occur as long ridges with relatively high elevation, which made them be seen conspicuously as shown in Fig. 1. Their strike lines run in the northsouth direction, between $40^{\circ}$ and $350^{\circ}$ with a consistent easterly dipping [9]. Banded gneiss outcrops in the Western and North-eastern part of Ibadan. They strike along the North direction with average dip angles of $47^{\circ} \mathrm{W}$ and $36^{\circ} \mathrm{E}$. They are obliterated in some places by intrusive veins and dykes. Minor structures such as folds, shear zones, pinch and swell structures, concordant and discordant quartz veins and quartz-feldspathic intrusions are present on the banded gneiss. Granite gneiss covers a small portion of Ibadan. They rarely outcrop and where they do, boulders appear with it. The general strike direction trends in N-S with dip angle of $47^{\circ} \mathrm{E}$ and are characterized by joints and faults in some cases [9].

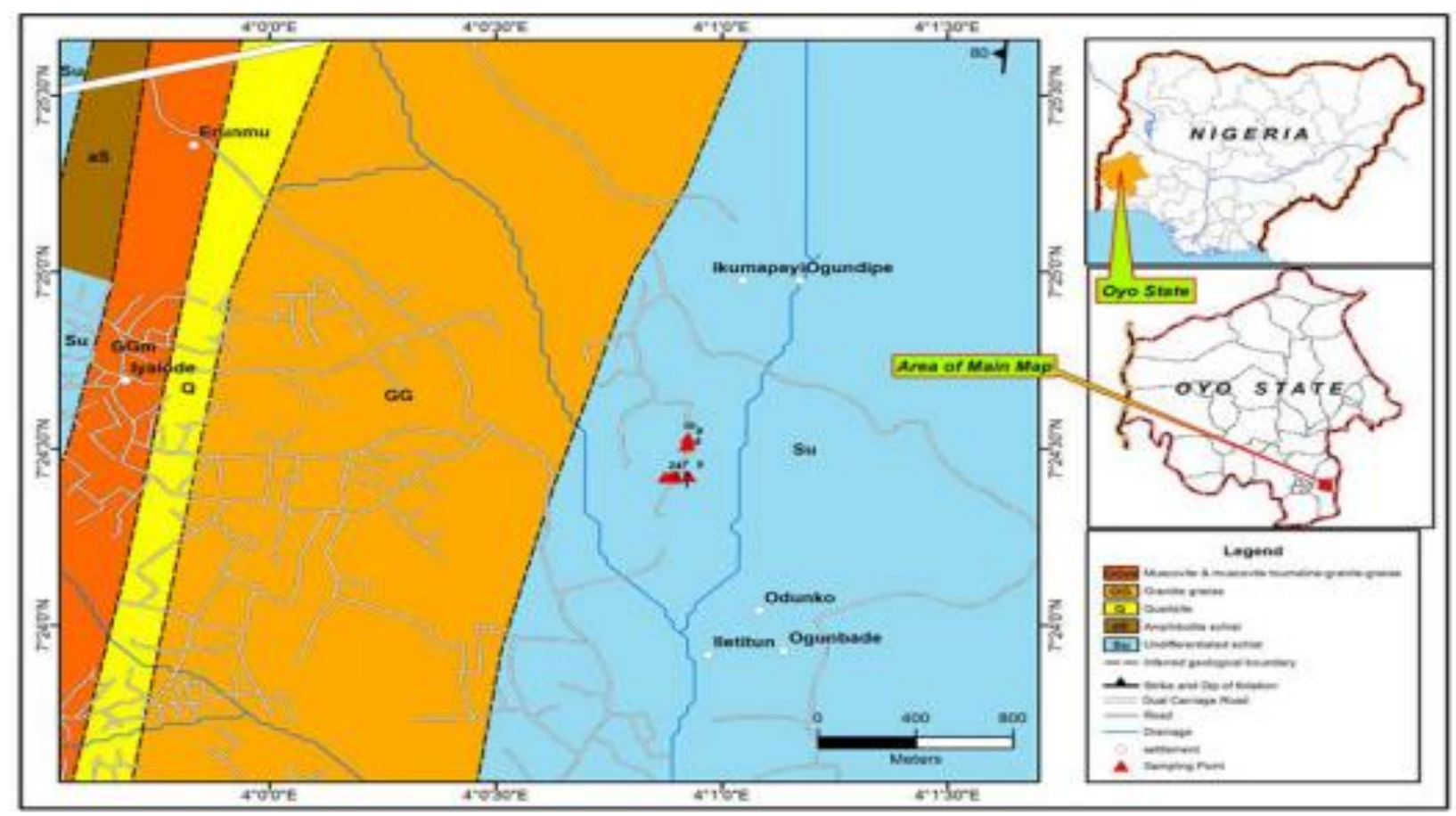

Figure 1. Geological Map of the Study Area. Adapted from [18] 


\section{Method and materials}

\subsection{Acquisition of VES Data and Water Samples collection}

Using ABEM SAS 1000 Terrameter, and Schlumberger electrode configuration, a total of fifteen Vertical Electrical Soundings (VES) were conducted on all sides of the battery waste dumpsite with a maximum of four VES on the North, East, and West sides and three VES on the South of the dumpsite. Due to the blockage of residential buildings on all four sides, measurement of distance and the conduction of the first VES on each side had to commence and conducted at a distance of $50.0 \mathrm{~m}$ away from the dumpsite. A total distance of $80.0 \mathrm{~m}$ was covered on the North, East and West sides while $70.0 \mathrm{~m}$ distance was covered on the South side of the dumpsite. All VES Data were collected at a space of eight days (between $6^{\text {th }}$ and $13^{\text {th }}$ August 2019). Using thoroughly washed five bottles and each was carefully rinsed with the water from each well before collection, five water samples from five different hand-dug wells were collected from five different locations on the four sides (two samples from the South and one sample each from the West, East and North) of the dumpsite as indicated in Table 2. At the point of collection and before testing and detecting the presence of lead in all these water samples, $2 \mathrm{ml}$ of concentrated Hydrochloric was added to each sample to retain the metal presence. Later these samples were taken to the Multidisciplinary Central Research laboratory of the University of Ibadan for metal testing and detection.

\subsection{Treatment and analysis of VES and water samples}

All the obtained VES data were first plotted on log-log sheets and a partial curve match method was used to obtain initial data. These initial data were fed into a WIN RESIST version 1.0 software for necessary iterations and synchronization to produce the number of layers, apparent resistivity, thickness and depth of the soil layer concern. The lowest apparent resistivity values obtained in each VES point were converted to apparent conductivity and were plotted against the distance of each VES Point

In the Multidisciplinary Central Research laboratory of the University of Ibadan, Atomic Absorption Spectrometer (AAS) was used to analyze the five collected water samples from five different hand-dug wells around the dumpsite to the concentration of lead if any in all these water samples. 


\section{Results and Discussions}

\subsection{Vertical Electrical Soundings (VES) results and discussion}

Table 1 presents the respective apparent resistivity, the number of layers, thickness, and curve type as obtained from the analysis of all the VES points conducted around Ori - Ile battery dumpsite. It also indicated the direction along which these VES points were conducted. The quantity interpretation of the sounding data gave three and four layers to be present at the dumpsite. The first layer is the topsoil, with the second and third layers being sandy-clayed while the third and fourth layers are weathered basement and basement.

The lowest resistivity values were recorded on the second and third layer on the East, South, West, and North sides of the waste dumpsite. The lowest resistivity values range of $1.3 \Omega$ $\mathrm{m}$ to $5.8 \Omega \mathrm{m}$ were recorded and prominent on the South side of the dumpsite, an indication of the presence of the lead metal ions concentration which had migrated from the dumpsite to the surrounding to a distance of $80 \mathrm{~m}$ away from the dumpsite. The increase in these lowest resistivity values as obtained from this side as one move away is an indication of the decrease in the concentration of the lead ions which is in agreement with the findings of [19]. On the South side of the Battery waste dumpsite, the lead ion had penetrated to a depth range of 0.5 to $5.2 \mathrm{~m}$. The lowest resistivity values as recorded on the remaining three sides - East, West and North of the dumpsite ranged from 3.0 to $26.3 \Omega \mathrm{m}, 13.6$ to.32.0 $\Omega \mathrm{m}$, and 9.5 to $44.9 \Omega \mathrm{m}$ respectively and are within the $80 \mathrm{~m}$ distance covered. The increase in resistivity as we moved away is an indication of the reduction of the concentration of the lead ions. The low resistivity values obtained due to the presence of lead ions might constitute a health hazard to the people living around this dumpsite since the majority depend on hand-dug wells and motorized borehole water for drinking and domestic uses. The lead ions have penetrated to the depth of 0.6 to $4.7 \mathrm{~m}, 0.5$ to 5.2 and 0.5 to $5.8 \mathrm{~m}$ on the East, West, and North sides respectively.

\subsection{Results and discussion of variation of apparent conductivity with distance}

The apparent lowest resistivity values obtained from the VES data analysis were converted to apparent conductivity and a graph of apparent conductivity against VES distance from the dumpsite was plotted for each side of the dumpsite. Figures 2 to 5 indicated the result of the plotting. On the South side of the dumpsite, the conductivities were relatively low and decreasing with distance, an indication of reduction of lead ion concentration with distance. Further 
investigation might show that this curve will not intercept the distance axis but constantly an indication that the lead ions will travel far with groundwater. On the other three sides, East, North, and West, the curved obtained Figures 2 to 5 also indicated that the apparent conductivity values were relatively low and reduce with distance but with further investigations, there is the tendency of the curve of the East side to intercept the distance axis and then the water will become safe for various uses while the remaining curves may not intercept the distance axis and but become nearly constant. This suggests that the contaminant (lead ions) had travelled far along the horizontal axis [20].

Table 1. VES Data Analysis Result

\begin{tabular}{|c|c|c|c|c|c|c|}
\hline $\begin{array}{l}\text { VES } \\
\text { Point }\end{array}$ & $\begin{array}{l}\text { Latitude and } \\
\text { Longitude }\end{array}$ & Layer & $\begin{array}{c}\text { Resistivity } \\
(\Omega \mathrm{m})\end{array}$ & $\begin{array}{c}\text { Depth } \\
\text { (m) }\end{array}$ & $\begin{array}{l}\text { Curve } \\
\text { Type }\end{array}$ & Direction \\
\hline \multirow[t]{3}{*}{1} & $\mathrm{~N} 7^{\circ} 24^{\prime} 25.1^{\prime \prime}$ & 1 & 102.4 & 1.6 & $\mathrm{H}$ & East \\
\hline & $\mathrm{E} 4^{\circ} 00^{\prime} 53.5^{\prime \prime}$ & 2 & 3.0 & 2.1 & & \\
\hline & & 3 & 268.9 & - & & \\
\hline \multirow[t]{3}{*}{2} & $\mathrm{~N} 7^{\circ} 24^{\prime} 25.1^{\prime \prime}$ & 1 & 87.4 & 0.7 & $\mathrm{H}$ & East \\
\hline & $\mathrm{E} 4^{\circ} 00^{\prime} 53.8^{\prime \prime}$ & 2 & 21.1 & 4.0 & & \\
\hline & & 3 & 442.9 & - & & \\
\hline \multirow[t]{3}{*}{3} & $\mathrm{~N} 7^{\circ} 24^{\prime} 25.1^{\prime \prime}$ & 1 & 330.4 & 0.6 & $\mathrm{H}$ & East \\
\hline & $\mathrm{E} 4^{\circ} 00^{\prime} 53.1^{\prime \prime}$ & 2 & 26.3 & 4.7 & & \\
\hline & & 3 & 4755.3 & - & & \\
\hline \multirow[t]{3}{*}{4} & $\mathrm{~N} 7^{\circ} 24^{\prime} 25.0^{\prime \prime}$ & 1 & 19.2 & 0.5 & $\mathrm{H}$ & South \\
\hline & $\mathrm{E} 4^{\circ} 00^{\prime} 53.7^{\prime \prime}$ & 2 & 1.3 & 1.8 & & \\
\hline & & 3 & 1024.1 & - & & \\
\hline \multirow[t]{3}{*}{5} & $\mathrm{~N} 7^{\circ} 24^{\prime} 30.5^{\prime \prime}$ & 1 & 96.8 & 0.6 & $\mathrm{H}$ & South \\
\hline & $\mathrm{E} 4^{\circ} 00^{\prime} 55.3^{\prime \prime}$ & 2 & 3.9 & 2.9 & & \\
\hline & & 3 & 1385.4 & - & & \\
\hline \multirow[t]{3}{*}{6} & $\mathrm{~N} 7^{\circ} 24^{\prime} 25.2^{\prime \prime}$ & 1 & 272.2 & 0.6 & $\mathrm{H}$ & South \\
\hline & $\mathrm{E} 4^{\circ} 00^{\prime} 53.8^{\prime \prime}$ & 2 & 5.7 & 5.2 & & \\
\hline & & 3 & 1027 & - & & \\
\hline \multirow[t]{3}{*}{7} & $\mathrm{~N} 7^{\circ} 24^{\prime} 25.3^{\prime \prime}$ & 1 & 104.3 & 0.8 & $\mathrm{H}$ & South \\
\hline & $\mathrm{E} 4^{\circ} 00^{\prime} 53.6^{\prime \prime}$ & 2 & 5.8 & 3.1 & & \\
\hline & & 3 & 216.1 & - & & \\
\hline \multirow[t]{3}{*}{8} & $\mathrm{~N} 7^{\circ} 24^{\prime} 28.4^{\prime \prime}$ & 1 & 49.5 & 0.5 & KA & West \\
\hline & $\mathrm{E} 4^{\circ} 00^{\prime} 50.8^{\prime \prime}$ & 2 & 13.6 & 1.0 & & \\
\hline & & 3 & 728.5 & - & & \\
\hline 9 & $\mathrm{~N} 7^{\circ} 24^{\prime} 31.8^{\prime \prime}$ & 1 & 50.7 & 1.5 & KH & West \\
\hline
\end{tabular}




\begin{tabular}{|c|c|c|c|c|c|c|}
\hline & \multirow[t]{3}{*}{$\mathrm{E} 4^{\circ} 00^{\prime} 55.5^{\prime \prime}$} & 2 & 138.1 & 1.6 & & \\
\hline & & 3 & 23.3 & 4.8 & & \\
\hline & & 4 & 615.9 & - & & \\
\hline \multirow[t]{3}{*}{10} & $\mathrm{~N} 7^{\circ} 24^{\prime} 28.4^{\prime \prime}$ & 1 & 131.7 & 0.7 & $\mathrm{H}$ & West \\
\hline & $\mathrm{E} 4^{\circ} 00^{\prime} 50.5^{\prime \prime}$ & 2 & 27.2 & 5.2 & & \\
\hline & & 3 & 554.9 & - & & \\
\hline \multirow[t]{3}{*}{11} & $\mathrm{~N} 7^{\circ} 24^{\prime} 28.4^{\prime \prime}$ & 1 & 474.3 & 0.4 & $\mathrm{H}$ & West \\
\hline & $\mathrm{E} 4^{\circ} 00^{\prime} 49.7^{\prime \prime}$ & 2 & 32.0 & 4.3 & & \\
\hline & & 3 & 967.8 & - & & \\
\hline \multirow[t]{3}{*}{12} & $\mathrm{~N} 7^{\circ} 24^{\prime} 28.4^{\prime \prime}$ & 1 & 50.9 & 0.8 & $\mathrm{H}$ & North \\
\hline & $\mathrm{E} 4^{\circ} 00^{\prime} 51.4^{\prime \prime}$ & 2 & 9.5 & 4.1 & & \\
\hline & & 3 & 1483.6 & - & & \\
\hline \multirow[t]{3}{*}{13} & $\mathrm{~N} 7^{\circ} 24^{\prime} 30.9^{\prime \prime}$ & 1 & 116.4 & 0.6 & $\mathrm{H}$ & North \\
\hline & $\mathrm{E} 4^{\circ} 00^{\prime} 55.5^{\prime \prime}$ & 2 & 10.5 & 1.7 & & \\
\hline & & 3 & 269.8 & - & & \\
\hline \multirow[t]{4}{*}{14} & N7 ${ }^{\circ} 24^{\prime} 31.4^{\prime \prime}$ & 1 & 56.6 & 0.5 & $\mathrm{KH}$ & North \\
\hline & $\mathrm{E} 4^{\circ} 00^{\prime} 55.5^{\prime \prime}$ & 2 & 191.7 & 2.7 & & \\
\hline & & 3 & 42.5 & 5.2 & & \\
\hline & & 4 & 1262.7 & - & & \\
\hline \multirow[t]{4}{*}{15} & $\mathrm{~N} 7^{\circ} 24^{\prime} 25.2^{\prime \prime}$ & 1 & 15.7 & 3.6 & $\mathrm{KA}$ & North \\
\hline & $\mathrm{E} 4^{\circ} 00^{\prime} 53.5^{\prime \prime}$ & 2 & 104.8 & 4.0 & & \\
\hline & & 3 & 44.9 & 5.8 & & \\
\hline & & 4 & 2179.2 & - & & \\
\hline
\end{tabular}

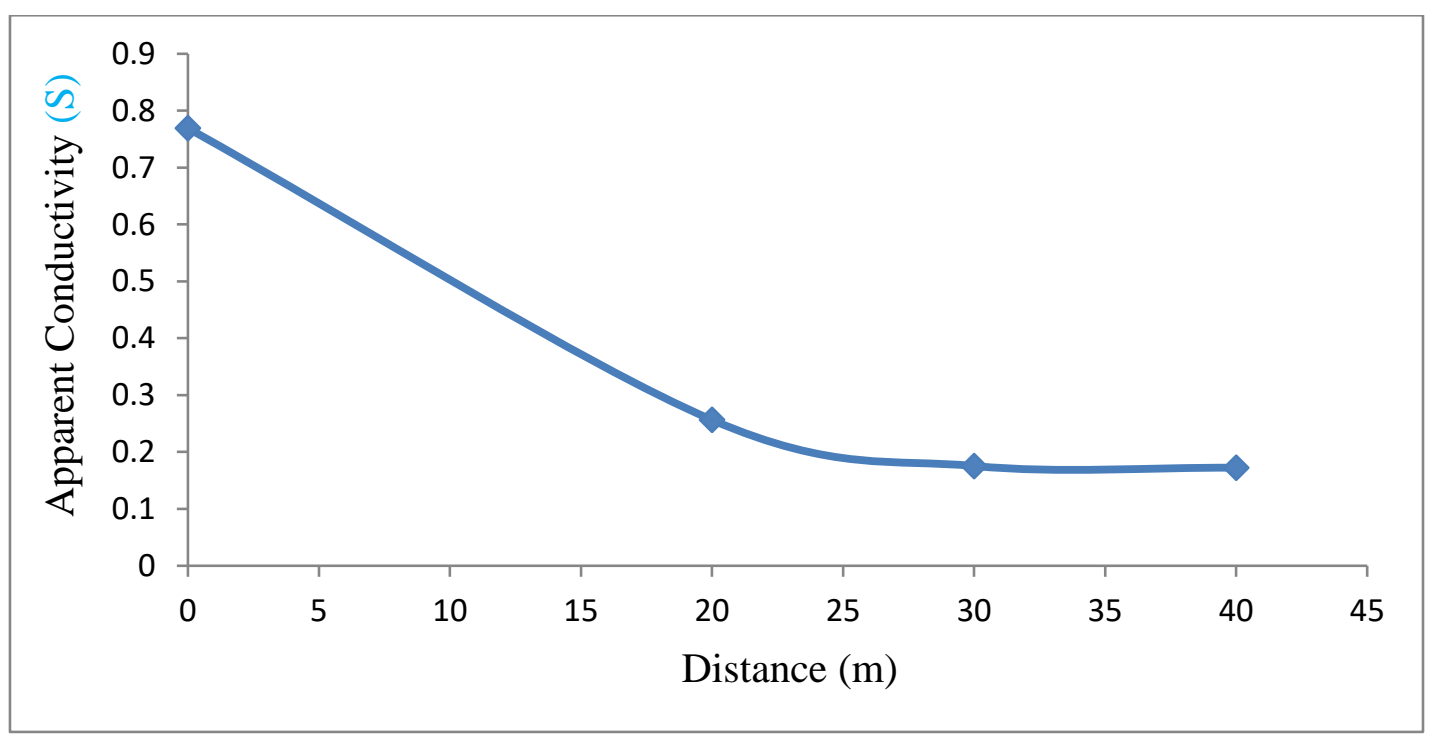

Figure 2. Variation of Conductivity with VES Distance (South side) 


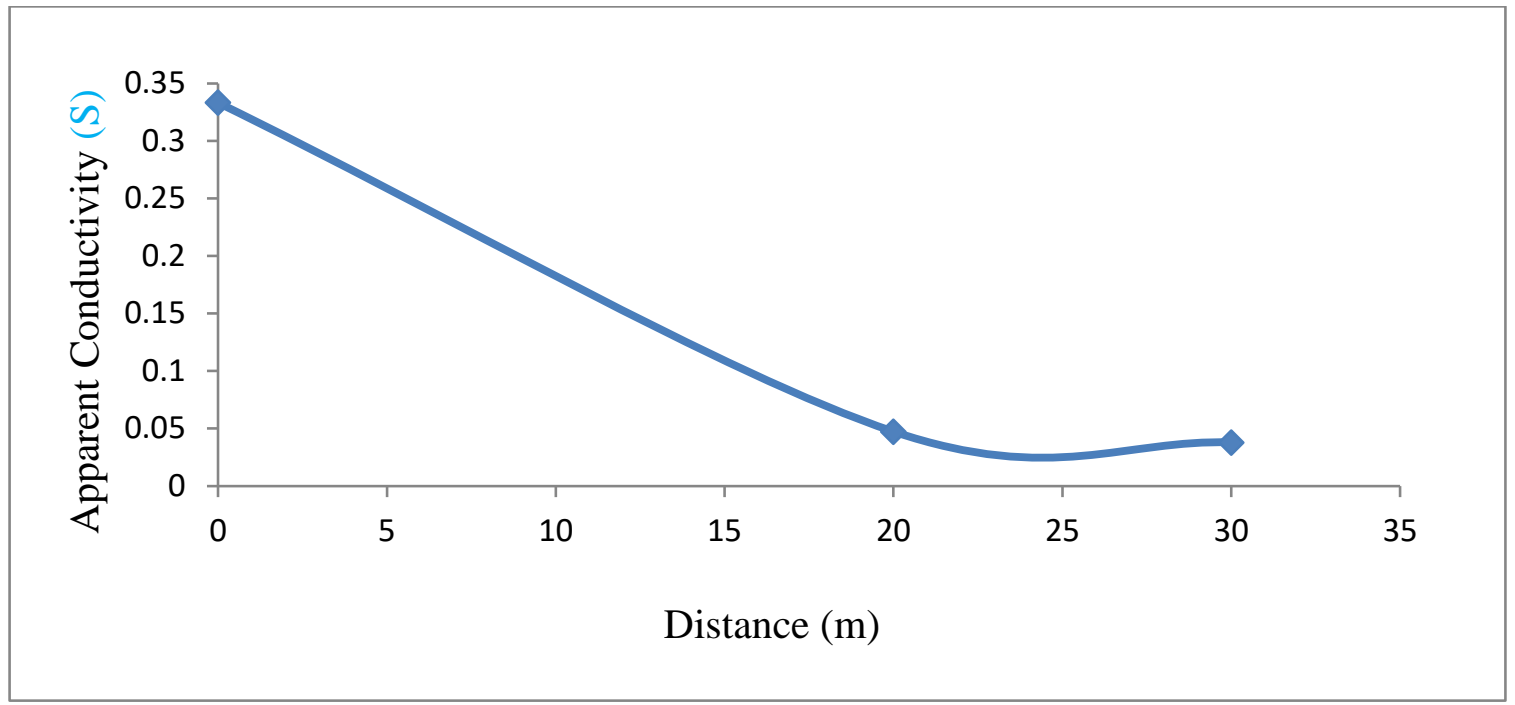

Figure 3. Variation of Conductivity with VES Distance (East side)

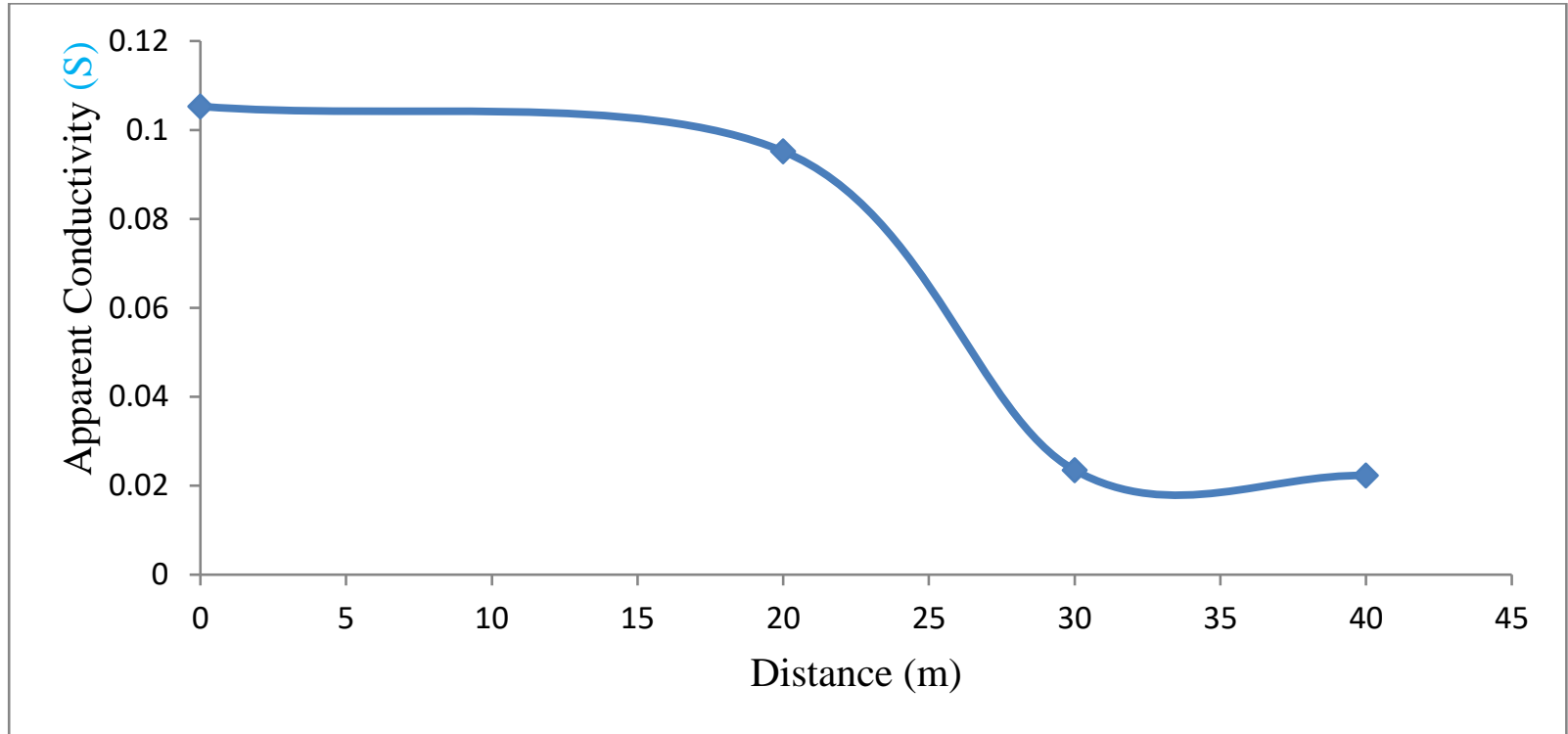

Figure 4. Variation of Conductivity with VES Distance (North side) 


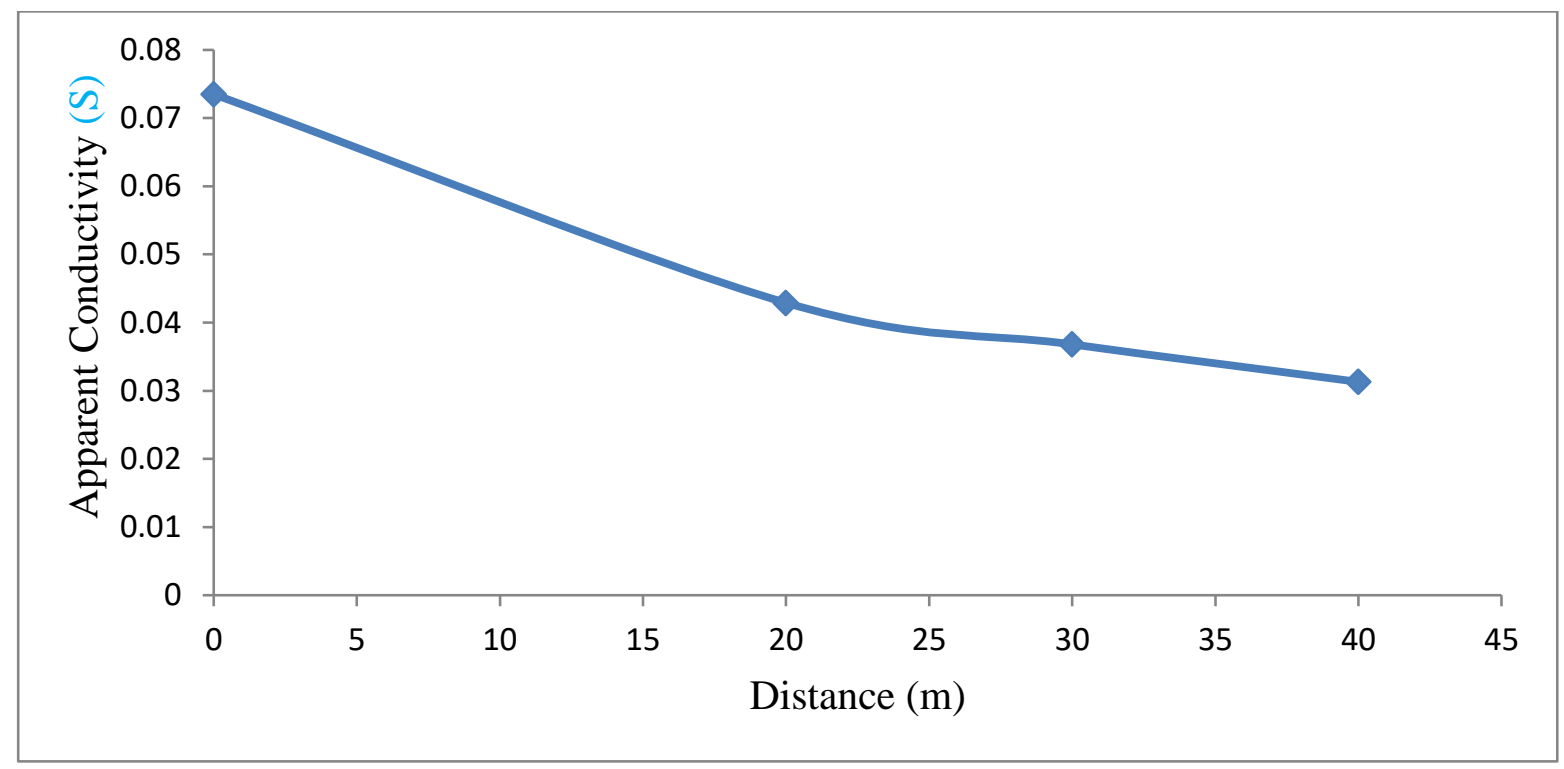

Figure 5. Variation of Conductivity with VES Distance (West side)

\subsection{Results and discussion of the Analysis of Water samples from Hand Dug Wells}

Table 2 shows the result of the water analysis carried out to determine the concentration of lead in water samples collected from five different hand-dug wells around the dumpsite. Lead was detected in all the water samples collected from within $80 \mathrm{~m}$ around the dumpsite. The concentration of the lead exceeded the allowed thresholds of $0.01 \mathrm{mg} / \mathrm{L}$ by the World Health Organization (W.H.O) [21] and Standard Organization of Nigeria (SON) [22]. Wells B and C on the southern section of the dumpsite had the highest concentration of lead $(0.770 \mathrm{mg} / \mathrm{L}$ and 0.452 $\mathrm{mg} / \mathrm{L}$ respectively). This was expected because the wells were located towards the bottom of a slope and since underground topography was expected to follow the same pattern as that of the surface, the heavy metal contaminant would flow to this location [9]. The results from the resistivity survey also confirmed that the concentration of lead ions contaminants in this region was very high. The concentration of lead detected in Well E (on the north) was $0.367 \mathrm{mg} / \mathrm{L}$ while water from Well D (East) had the lead concentration of $0.134 \mathrm{mg} / \mathrm{L}$. Well A (on the North) had the least concentration of lead ion contaminant $(0.081 \mathrm{mg} / \mathrm{L})$. This however, has far exceeded the standard limit of $0.01 \mathrm{mg} / \mathrm{L}$ of both WHO and SON. This well is located towards the top of the slope and it is expected that the contaminants flowed away from this location as confirmed by the high resistivity values obtained from the resistivity survey. 
Table 2. Comparison of water analysis results with recommended standards

\begin{tabular}{|c|c|c|c|c|}
\hline $\begin{array}{l}\text { Water } \\
\text { Sample }\end{array}$ & $\begin{array}{l}\text { Latitude and } \\
\text { Longitude }\end{array}$ & $\begin{array}{l}\text { Well Distance from } \\
\text { Dumpsite }(\mathrm{m})\end{array}$ & $\begin{array}{l}\text { Depth to water } \\
\text { table }(\mathrm{m})\end{array}$ & $\begin{array}{l}\text { Lead Concentration } \\
(\mathrm{mg} / \mathrm{L})\end{array}$ \\
\hline Well A & $\mathrm{N}^{\circ} 24^{\prime 2} 29.1^{\prime \prime}$ & 55.0 & 6.0 & 0.081 \\
\hline (North) & $\mathrm{E} 4^{\circ} 00^{\prime} 52.3^{\prime \prime}$ & & & \\
\hline Well B & $\mathrm{N} 7^{\circ} 24^{\prime} 25.1^{\prime \prime}$ & 61.0 & 5.6 & 0.770 \\
\hline (South) & $\mathrm{E} 4^{\circ} 00^{\prime} 53.5^{\prime \prime}$ & & & \\
\hline Well C & $\mathrm{N}^{\circ} 24^{\prime} 25.0^{\prime \prime}$ & 75.0 & 5.2 & 0.452 \\
\hline (South) & $\mathrm{E} 4^{\circ} 00^{\prime} 53.7^{\prime \prime}$ & & & \\
\hline Well D & $\mathrm{N} 7^{\circ} 24^{\prime 25.1}$ & 65.0 & 7.3 & 0.134 \\
\hline (West) & $\mathrm{E} 4^{\circ} 00^{\prime} 53.1^{\prime \prime}$ & & & \\
\hline Well E & $\mathrm{N} 7^{\circ} 24^{\prime \prime} 30.3^{\prime \prime}$ & 73.0 & 8.0 & 0.367 \\
\hline (East) & $\mathrm{E} 4^{\circ} 00^{\prime} 54.5^{\prime \prime}$ & & & \\
\hline
\end{tabular}

W.H.O standard (2004) [21] and S.O.N standard (2007) [22] for Lead concentration in water is $0.01 \mathrm{mg} / \mathrm{L}$

\section{Conclusion}

The electrical resistivity method was successfully used for the determination of heavy metal spread outside Ori-Ile dumpsite. The results of the electrical resistivity model showed the vertical extent of the contaminated zones and as well as the subsurface contaminant pathways which indicated low resistivity (or high conductivity) values because of the presence of lead ions. The results obtained from water analysis using the Atomic Absorption Spectrometer (AAS) were in agreement with the results of the resistivity survey. Results from the southern region showed the lowest values of apparent resistivity indicating that the region has the highest concentration of heavy metals. Water samples from Well B and Well C from this region had the highest concentration of lead. The soil and underground water from this region are highly contaminated with lead and other heavy metals. Next to the southern region is the east, followed by the West. The north side of the dumpsite had the least concentration of heavy metal contaminants. Water from Well A located in this region had the least concentration of lead $(0.081 \mathrm{mg} / \mathrm{L})$. This is still hazardous because the standard limit set by the World Health Organization and the Standard organization of Nigeria for the concentration of lead in natural mineral waters is $0.01 \mathrm{mg} / \mathrm{L}$. This study therefore concludes that the distance within $80 \mathrm{~m}$ on all 
sides from Ori-Ile dumpsite is contaminated with heavy metals, with the contamination spreading most on the southern region of the dumpsite.

\section{References}

[1] S. Vaalgamaa, and D. J. Conley, Detecting environmental change in estuaries: nutrient and heavy metal distributions in sediment cores in estuaries from the Gulf of Finland, Baltic Sea”. Estuarine, Coastal and Shelf Science.76(1): (2008). 45-56.

[2] E. S. Dadzie. Assessment of heavy metal contamination of the Densu River, Weija from Leachate. M.Sc. Thesis. Department of Theoretical and Applied Biology, Kwame Nkrumah University of Science and Technology, Ghana. (2012).

[3] H. M. Salem, A. Eweida, and F. Azza, Heavy metals in drinking water and their environmental impact on human health, Center for Environmental Hazards Mitigation, (2000). 542- 556.

[4] M. A. Adabanija, and T. O Alabi. An Integrated approach to mapping the concentration and pathway of leachate plumes beneath a dump site in South-western Nigeria. International Journal of Scientific and Engineering Research, 5 (1): 1565-1571 (2014).

[5] P. I. Orjiakor, and E. I. Atuanya. Effects of automobile battery wastes on physiochemical properties of soil in Benin City, Edo State. Global Journal of Pure and Applied Sciences (2015).21:129-136.

[6] J.A. Adegoke, T.O. Owoyokun, and I.O. Amore. "Open Land Dumping: An Analysis of Heavy Metals Concentration of an Old Lead-Battery Dumpsite”. Pacific Journal of Science and Technology (2009). 10 (2): 592-595.

[7] V.A. Asaah, and A.F Abimbola. Heavy Metal Concentrations and Distribution in Surface Soils of the Bassa Industrial Zone 1, Douala, Cameroon. The Arabian Journal for Science and Engineering, (2006). 31: 2-8

[8] M. Vaccari, G. Vinti, and T. Tudor. An analysis of the risk posed by leachate from dumpsite in developing countries. Environments, (2018). 5 (99):1-17.

[9] J.A Adegoke, and E. O Olufosokan. Electrical resistivity and VLF-EM methods for the study of spread of some heavy metal contaminants in an old lead-battery dumpsite. Nigerian Journal of Science (2015). 49: 23-36 
[10] P. N. Okanigbuan, and O. R Okanigbuan. Determination of heavy metals in dump site using resistivity method in Ugbor road, Benin City, Nigeria, Journal of Basic and Applied Sciences, 2(1): 34 - 42, (2016).

[11] M.A. Nwachukwu, H. Feng, and J. Alinnor. Assessment of Heavy metal pollution in soil and their implication within and around Mechanic Villages. International Journal of Environmental Science and Technology7(2): 347-358. (2010).

[12] G. Guanlin, Z. Qixing, and Q. M. Lene. Availability and assessment of fixing additives for the in-situ remediation of heavy metals contamination soil Environmental Monitoring and Assessment, 116: 515-528. (2005).

[13] A. O. Afolayan, and A. T. Hassan. Lead, Cadmium and Iron Concentrations in Zea Mays Grown Within the Vicinity of Ori-Ile Battery Waste Dumpsite, Olodo, Ibadan, Nigeria. American Journal of Bioscience and Bioengineering 5 (5): 92-103 (2017).

[14] W.E. Wightman, F. Jalinoos, P. Sirles, and K. Hanna. Application of Geophysical Methods to Highway Related Problems. Federal Highway Administration, Central Federal Lands Highway Division, Lakewood. (2003).

[15] M. Meju. Geoelectrical investigation of old abandoned covered landfills in urban areas: Model development with a generic diagnosis approach. Journal of Applied Geophysics4: 115 -150. (2010).

[16] C. Agbo. 2D Electrical Resistivity Imaging around the collapsed Buildings of the Housing Estate at Barnawa - Narayi Junction, Kaduna, Kaduna State. M.Sc. Thesis, Department of Physics, Ahmadu Bello University, Zaria. xiii - (2014). 66

[17] V. Modebelu. Exide Batteries epitaph: Here lies in waste a multi-million-naira investment.https://groups.yahoo.com/neo/groups/NIgerianWorldForum/conversations/topics/1

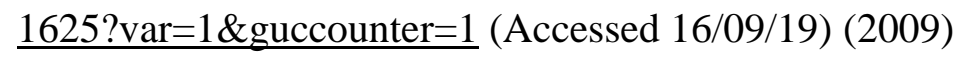

[18] N. K. Grant. Geochronology of Precambrian basement rocks from Ibadan. Earth and planetary Science Newsletter 10 (1):29 - 38. (1970)

[19] J. L., Porsani, W. M. Filho, V. R Elis, F. Shimeles, J. C. Dourado, and H. P Moura. The use of GPR and VES in delineating a contamination plume in a landfill site: A case study in SE Brazil. Journal of Applied Geophysics, 55: 199-209. (2004). 
[20] S. B. Jodeiri, A. F. Doulati, and A. Moradzadeh Mapping the flow pathways and contaminants transportation around a coal washing plant using the VLF-EM, geoelectrical and IP techniques - A case study in NE Iran. Environment and Earth Science, 75: 62. (2016).

[21] World Health Organization (W. H. O.) World Health Report. Retrieved on May 1, 2015 from HTTP: www.who.int/whr/2004/en/report04en.pdf. (2004).

[22] Standard Organization of Nigeria (S. O. N.) Nigeria Industrial Standard for Natural Mineral Waters. 345 - 347. (2007). 